\title{
Framings and coverage of climate change in Swedish specialized farming magazines
}

Therese Asplund, Mattias Hjerpe and Victoria Wibeck

\section{Linköping University Post Print}

N.B.: When citing this work, cite the original article.

The original publication is available at www.springerlink.com:

Therese Asplund, Mattias Hjerpe and Victoria Wibeck, Framings and coverage of climate change in Swedish specialized farming magazines, 2012, Climatic Change.

http://dx.doi.org/10.1007/s10584-012-0535-0

Copyright: Springer Verlag (Germany)

http://www.springerlink.com/?MUD=MP

Postprint available at: Linköping University Electronic Press

http://urn.kb.se/resolve?urn=urn:nbn:se:liu:diva-80851 


\title{
Title page: Framings and coverage of climate change: a study of Swedish specialized farming magazines
}

Therese Asplund $^{1 *}$, Mattias Hjerpe ${ }^{1}$, Victoria Wibeck ${ }^{1}$

${ }^{1}$ Centre for Climate Science and Policy Research and Department of Thematic Studies -Water and Environmental Studies, Linköping University

* Corresponding author: Therese Asplund, therese.asplund@liu.se, phone: +46 11 363397, fax: +46

113632 92. Postal address: Centre for Climate Science and Policy Research, Linköping University, SE-601 74, Norrköping, Sweden

\begin{abstract}
Climate change is a fundamental challenge for which agriculture is sensitive and vulnerable. The Intergovernmental Panel on Climate Change has identified relevant information as key to enabling appropriate climate adaptation and mitigation action. Information specifically directed to farmers can be found, for example, in specialized farming magazines. While recent studies examine how national news media frame climate change, less- if any- studies have addressed climate framings and coverage in specialized media. Media framings are storylines that provide meaning by communicating how and why an issue should be seen as a problem, how it should be handled, and who is responsible for it. This paper analyses the framings and coverage of climate change in two Swedish specialized farming magazines from 2000 to 2009. It examines the extent of the climate change coverage, the content of the media items, and the dominant framings underlying their climate change coverage. The study identifies: increased coverage of climate change starting in 2007; frequent coverage of agriculture's contribution to climate change, climate change impacts on agriculture, and consequences of climate politics for agriculture; and four prominent frames: conflict, scientific certainty, economic burden, and action. The paper concludes that climate change communicators addressing farmers and agricultural extension officers should pay attention to how these frames may be interpreted by different target audiences. Research is needed on how specialized media reports on climate-related issues and how science-based climate information is understood by different groups of farmers and which other factors influence farmers' engagement in climate mitigation and adaptation.
\end{abstract}

Keywords: media representation, media frames, farming magazines, climate change communication; specialized media 


\section{Framings and coverage of climate change in Swedish specialized}

\section{farming magazines}

\section{Introduction}

As a top priority on the global political agenda, climate change is claimed to be one of the most fundamental challenges ever to confront humanity. Although climate change affects all sectors, agriculture is among the most vulnerable and sensitive. Agricultural production and farmers' daily lives will increasingly be influenced by changes in temperature and precipitation challenging the adaptive capacity of the agricultural sector (FAO 2008). Farmers in industrialized countries are also crucial for mitigating climate change.

The Intergovernmental Panel on Climate Change (IPCC 2007, SOU 2007:60) has identified relevant climate information as key for enabling appropriate climate change adaptation and mitigation action. Thus, knowledge of the availability and content of information for farmers is key to understanding how production patterns might be altered (Brunn and Raitz 1978).

Communicating the realities of climate change is indeed challenging. Barriers to public engagement include various individual and social constraints, among others lack of knowledge, distrust in information sources, reluctance to change lifestyles, and pressure of social norms and expectations (Lorenzoni et al. 2007). To our knowledge, no previous studies have examined how specialized agricultural-sector media communicate climate change, even though their importance as sources of information for Swedish farmers has been demonstrated (LRF 2009).This paper analyzes how climate change has been communicated in specialized media targeting farmers. Thus, it addresses "one of the most easily identifiable barriers to 
engagement", i.e. "lack of basic knowledge about knowledge about causes, impacts and solutions to climate change" (Lorenzoni et al. 2007:451). Analyses of how specialized farming magazines frame and cover climate change could give insights into how climate science and policy are communicated to a group of actors pointed out as central for climate change mitigation and adaptation. Framings are here seen as meaning-providing organizing ideas or storylines (Gamson and Modigliani 1987; Olausson 2009). While "quality" newspapers have been frequently studied, few have studied media representations of climate change in special-interest magazines. This paper is one contribution to the recent calls for more case-specific and audience-specific research (Moser 2010), including larger social and cultural groupings (Whitmarsh and Lorenzoni 2010) such as farmers.

The paper departs from the Swedish context; Sweden exemplifies a country where agriculture is predicted to gain through longer growing seasons. The Swedish government is promoting liberalization of trade in agricultural products, and has modified subsidies and taxes to strengthen the incentive for climate change mitigation (Swedish Government Bill 2009; SEPA 2012). The Swedish news media and tabloids have paid considerable attention to climate change (Westander et al. 2008), framing it as a social problem and stressing the need for collective action (Olausson 2009). Swedish news stories tend to assume that "human-induced global warming is a direct cause of climate change, bringing with it dramatic consequences already at hand" (Olausson 2009:429).

This paper focuses on the two Swedish farm magazines with the largest national circulations: ATL - Lantbrukets affärstidning (ATL) and Land Lantbruk (Land). It analyses the framing and coverage of climate-related issues from 2000 to 2009 , guided specifically by the following questions: 
- To what extent do Swedish farm magazines report on climate change?

- Which themes and topics are covered?

- How is climate change framed in Swedish farming magazines?

- What are the differences between framing of climate change in Swedish farming magazines and in national news media?

- What lessons could be learnt from analysis of framing and coverage in specialized magazines for climate change communicators targeting farmers?

\section{Swedish agriculture and climate policy}

Sweden's land area is $410,000 \mathrm{~km}^{2}$ and the cultivated area comprises $6.5 \%$ of it (SBA, Swedish Board of Agriculture 2011). In 2005, the agricultural sector made up 0.5\% of GDP and provided $1.5 \%$ of total employment. In 2007, the production value of Swedish agriculture was SEK 47 billion ( EUR 4.89 billion), evenly distributed between livestock and crops. Swedish livestock mainly consists of bovine animals while cereals and grassland dominate crop production.

For Swedish agriculture, climate change poses both challenges and opportunities, but in a 25year perspective, the opportunities are viewed to outweigh the challenges (SOU 2007:60, SBA 2007). Climate change scenarios suggest higher temperatures and changing precipitation patterns bringing about higher yields and opportunities to grow new crops, but also risk of new crop pests and viruses that may infect animals (SBA 2007). Increasing and more intense precipitation along with more rapid snowmelt makes drainage and water availability highly challenging, scattered regionally, where climate change will aggravate flood risk, conflicts of interest, raise costs, and affect the crop yield negatively (SBA 2007, 2010b). In 2006 to 2010, 
agriculture and land use change in Sweden emitted 10 million tons of greenhouse gas (GHG) emissions annually; the largest GHG sources are nitrous oxide $\left(\mathrm{N}_{2} \mathrm{O}\right)$ emissions from soil and methane $\left(\mathrm{CH}_{4}\right)$ emissions from ruminant animals (SEPA 2012).

Regarding policy responses, the Swedish center-right alliance Government Bill from 2009 contains an integrated climate and energy policy aiming to reduce Sweden's dependency of fossil fuel and GHG emissions. It primarily addresses climate mitigation and only partially adaptation. As a member of the EU, Sweden is part of its climate and common agricultural policy (CAP). For the agricultural sector the CAP rural development program affects agricultural GHG emissions and adaptation. Sweden also has a national action plan to reduce $\mathrm{N}_{2} \mathrm{O}$, methane and carbon dioxide $\left(\mathrm{CO}_{2}\right)$ emissions (SBA 2010a). Farmers' use of fossil fuels has been subsidized by a fossil fuel tax reduction. In carrying out the Climate Bill, the Swedish unicameral Parliament in 2009 decided to partially phase out the fossil fuel tax reduction for agriculture by $9 \%$, which was implemented in 2011 and will be further reduced by $30 \%$ in 2015 . Furthermore, GHG emissions are expected to decrease on voluntary basis incentivized by information and agricultural extension, implying communication of climaterelated issues to individual farmers (Greppa Näringen 2011).

\section{Media framings of climate change}

In media studies, the "framing" concept means "a central organizing idea or story line that provides meaning to an unfolding strip of events, weaving a connection among them. The frame suggests what the controversy is about, the essence of the issue" (Gamson and Modigliani 1987:143). Framings communicate how and why the issue should be seen as a problem, how it should be handled, and who is responsible for it (Koteyko et al. 2010; Nisbet 
2009). Analysing how climate change was framed in the US media and political debate from the late 1990s and onwards, Nisbet and Scheufele (2009) identified these frames:

Economic development defines climate change as investment and competitiveness; Morality/ethics defines climate change in terms of right or wrong;

Scientific uncertainty defines climate change as a matter of what is known and unknown;

Pandora's box defines climate change as a call for precaution in face of possible catastrophe;

Public accountability defines climate change as responsible use or abuse of science; and

Conflict/strategy defines climate change as a game among groups.

Although underscoring the diversity of climate debates (Hulme 2009), previous studies on media frames of climate change have found the Pandora's box and conflict frames to be prominent. The former is evident in headlines and coverage articulating fear, misery, and doom (Boykoff 2008), describing climate change as sensational, alarming (Russil and Nyssa 2009) and harmful (Ambler 2007; Carvalho and Burgess 2005). Oppositely, Young and Dugas (2011) recently found, studying longitudinal trends, that Canadian media coverage of climate change paid less attention to impacts, instead emphasizing how it intersects with policy and business. Similarly, Lyytimäki (2011) suggests that, after a phase of widespread media coverage, climate issues will shift from highly visible headlines to being less visible, although more pervasive, background information. These findings suggest that the Pandora's box frame will fade away in future media coverage. 
The conflict frame portrays climate change as a source of conflict over the uncertainties of anthropogenic climate change or between the relative winners and losers from climate change (O'Brien and Leichenko 2000). While the idea of scientific uncertainty prevails in US news reporting on climate change (Freudenburg and Muselli 2010), media in several European countries, e.g. Sweden, France (Brossard et al. 2004), and Germany (Weingart et al. 2000), are reluctant to expose scientific uncertainty (Olausson 2009). In UK newspapers, narratives differ across newspapers and time; also regarding scientific uncertainty (Ambler 2007; Boykoff 2007), thus making the scientific uncertainty frame more problematic. When norms

of "balanced reporting"- i.e., giving roughly equal coverage to both sides in a disputeinfluences climate change coverage, this results in informational bias on the uncertainty regarding anthropogenic climate change, as climate skeptics are paid the same attention as the vast majority of scientists who acknowledge the anthropogenic roots of climate change (Boykoff and Boykoff 2004).

\section{Material and method}

This paper focuses on the two Swedish farm magazines with the largest national circulations and broad readership: ATL - Lantbrukets affärstidning (ATL, circulation 51,700) and Land Lantbruk (Land, circulation 118,700) (Swedish Magazine Publisher Association 2010). The magazines target similar readers, but differ in scope and editorial policy. Land is distributed to all members of the Federation of Swedish Farmers (LRF) and aims to "mirror what is happening in the farmers' movement" (LRF Media 2010a), while ATL features "tough journalism" (LRF Media 2010b). According to their websites, Land focuses on political, financial, social, and market issues, while ATL emphasizes market and business issues. 
The articles selected for analysis were identified from 1,500 issues of Land and ATL published between 2000 and 2009 totalling 11,000 front page news; about 20\% of all articles are displayed on the front page. As front page news draw attention to, and reflect the emphasis media place on certain issues, we consider such articles to have a strong agenda-setting influence (Scheufele and Tewksbury 2007). Being a relatively new topic, we believe that the news value of the climate change articles was high during the examined period. Selecting articles highlighted on the front page would thus be an appropriate strategy for limiting the sample to a manageable size. The full-length articles were then included in the data corpus for further analysis. We excluded articles that were not displayed on the front pages and articles primarily dealing with forestry due to our focus on agriculture. In a farming magazine, weather-related articles may be common, but to qualify as a climate-related article, we stipulated that it should contain at least one of following keywords: climate change/gas(es), global warming, greenhouse effect/gas(es), and carbon dioxide/emissions.

The selected articles form the basis of a quantitative analysis of the extent of farm magazines' coverage of climate change from 2000 to 2009. Additionally, a qualitative content analysis of sub-topics, topics, and themes was performed to determine what aspects of climate change were considered. Topic refers to the content of an article and each article was assigned a topic reflecting its general content and segmented into sub-topics reflecting various aspects of the topic. We grouped recurring topics in the corpus into themes. Analysing themes will provide insights into the aspects of climate change that are and are not covered. From this thematic analysis we proceed to discuss how climate change is framed, i.e. we focused on the underlying premises that are often taken for granted: the media report on the basis of these premises rather than about them. To address intercoder reliability, two researchers independently categorised the articles and compared the results. 


\section{Farming magazine coverage and framings of climate change}

From 2000 to 2009, we identified 113 climate-related articles in ATL and Land (Fig. 1). The number of articles increased markedly in both magazines after 2006. ATL's attention to climate change has followed a general increasing trend since 2006, whereas Land's attention first peaked in 2007 before increasing considerably again in 2009.

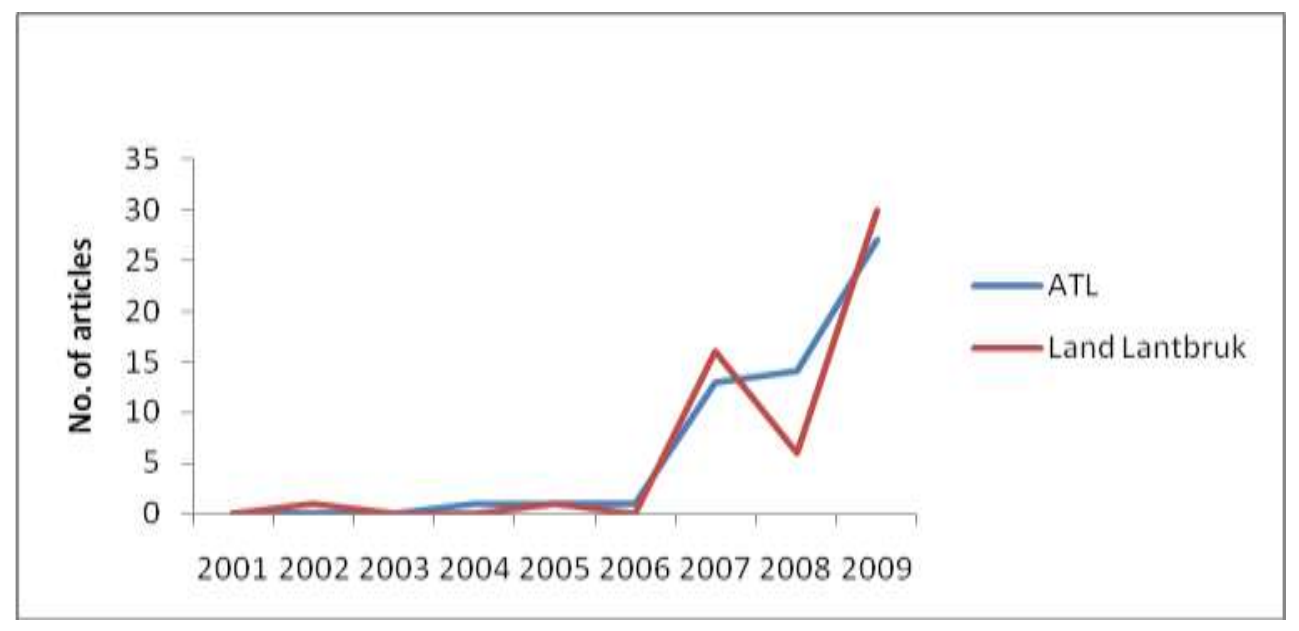

As Figure 1 shows, between 2000 and 2006 the magazines only occasionally paid attention to climate change, featuring seven climate-related articles. These articles concern enteric fermentation, reduction of EU emissions, environmental aspects of animal fodder, comparison of diesel fuels, and advocacy of farmer action. In 2007, the climate-related articles increased substantially in a similar form, but lagged in time, to changes in adaptation research (Janssen et al. 2006) and Nordic climate change research (NordForsk 2009).

In ATL, editorials were among the first published climate-related-articles, arguing that farmers should respond to climate change. This set the tone for ATL's subsequent climate change coverage. The rapid increase of climate-related articles in Land in 2007 is, in contrast, 
explained by the involvement of the LRF in the climate debate. One of Land's first climaterelated articles reports on LRF's concern about agriculture's contribution to climate change, particularly suggesting mapping emissions sources. With ensuing articles focusing on the causes of climate change and estimated emissions from agricultural practices this first bottom-up initiative made climate change visible and stimulated Land's coverage.

Similar patterns recurred in both magazines, with respect to article contents and frames. Three themes were found: agriculture's contribution to national emissions, the biophysical impacts of climate change on agriculture, and consequences of climate politics for agriculture. We present the themes chronologically, reflecting their first appearances in the magazines. While the agriculture's contribution to national emissions theme was covered in similar number of articles in 2007, 2008, and 2009, the impacts of climate change were paid more attention in 2007 and 2009 and less in 2008, slightly shifting focus from future impacts to observed changes. Climate-related articles on politics were almost exclusively published in 2009, the run-up to the UN Climate Conference in Copenhagen. Most climate-related articles concerned crop and cattle; few articles considered lamb and poultry. The crop production articles addressed one crop at a time, notably, less common crops in Sweden, e.g. sunflowers, and corn instead of common crops, e.g. potatoes.

\subsection{Agriculture's contribution to national emissions}

The agriculture's contribution to national emissions theme mostly concerned GHG emissions from agricultural activities, while limited attention was paid to carbon sinks. Throughout the period, the theme centred on enteric fermentation - the production of methane by ruminant livestock. The coverage of methane emissions from cows went through a remarkable transition from laughter about scientific findings to common sense regarding its importance. 
Coverage of the issue started in 2000 with articles ridiculing science for its findings about "cow farts" a,b , followed by articles explaining the process of enteric fermentation, until finally methane production was presented as a matter of common sense requiring no explanations.

Other articles concerned emissions from specific agricultural production systems, e.g. pea cultivation, and greenhouse-grown tomatoes. Although livestock emissions were widely discussed, there were calls for more nuanced debate on enteric fermentation in relation to other GHGs and a discussion of agriculture's contribution to national emissions. Nevertheless, the articles failed to inform readers about the general picture of agriculture's contribution to climate change. For example, few articles concerned $\mathrm{N}_{2} \mathrm{O}$ emissions from soil and manure. The studied farming magazines focussed on methane and emphasized emission reduction rather than sequestration in soil and vegetation.

The studied articles focused largely on agriculture's contribution to national emissions, but simultaneously downplayed the importance of GHG emissions from agriculture by presenting a conflict frame. Cow and beef breeding systems were compared, suggesting conflict between large- and small-scale, conventional and organic production systems. Articles also invoked a conflict between Swedish and Brazilian production systems regarding measurement, comparison, and evaluation of GHG emissions. Agriculture and transport sectors ("the motorist or the farmer", "the car or the steak" ) were repeatedly presented as a choice between two mutually exclusive objects. This tension was evident in articles that, on the one hand, reported on agricultural emissions reduction and, on the other hand, downplayed agriculture's contribution to national emissions by portraying other sectors as equally bad. Thus, we argue that introducing a conflict frame into the coverage of agriculture's contribution to national emissions also legitimized agriculture's GHGs emissions. 


\subsection{Climate change impacts on agriculture}

Coverage of impacts of climate change emphasized the domestic over the foreign perspective. It emphasised how a specific location is being and would be affected by climate change and pointed to local impacts rather than global impacts and vulnerability.

Climate change impacts were discussed mainly as opportunities and challenges facing Swedish agriculture, outlining how farmers would be financially affected by the changing climate. The magazines reported on the opportunities climate change would present for agriculture through higher demand for fossil-neutral energy crops, better weather conditions for tourism strengthening the incentives for agrotourism (encouraging visitors to experience agricultural life at first hand and diversifies farmers' incomes), and increasing yields because of improved climatic conditions. Fewer articles concerned the challenges climate change would bring, e.g. insufficient drainage capacity due to increasing precipitation and more pronounced snowmelt and pest outbreaks. By 2008, coverage of climate change impacts on agricultural production was focusing less on projected future challenges and opportunities, and was starting to report on observed phenological changes. For example, in 2009, articles reported on rapeseed in bloom too early, changing planting dates for autumn seeding, the cultivation of new crops, and local observations of increased temperature. Reporting on tangible impacts also shifted reader attention to the familiar, often from the individual perspective, instead of the abstract and remote. The articles rarely linked climate change to other environmental and social challenges. Presented as isolated from other issues, climate change is similarly presented as in early vulnerability and integrated assessment studies (O’Brien and Leichenko 2000). 
A frame of scientific certainty was used to organize coverage of the impacts of climate change on agriculture. Scientific findings regarding climate change impacts were framed as unquestionable evidence. There was a general lack of reflection on the various uncertainties in climate science, e.g. the accuracy of scenarios and models, lack of data, and scale problems in cause and effects. Thus, the scientific consensus, as represented by the IPCC, on anthropogenic climate change is reflected in the studied farming magazines. The scientific certainty frame ran throughout the material but was more marked for climate change impacts. By 2008, the magazines even reported their own observations of climate change, thus contributing to the overall scientific certainty frame. The focus on certainty at the expense of uncertainty suggests that the specialized magazine coverage could also be characterised as an oversimplification of scientific results.

\subsection{Consequences of climate politics for agriculture}

Many of the articles elaborated on the consequences of national, European, and global climate politics for agriculture. Nationally, the politics of the "safety net"e or crop insurance was on the agenda in 2007, while the perceived consequences of the centre-right alliance government's Climate Bill were highlighted in 2009. Given that the Bill's proposals would arguably result in economic loss and increased taxes for farmers, the opinion that it would help neither the climate nor the economy was emphasized. The rural and farmers party, Centern, is part of the centre-right alliance, which may explain the general disapproval of the Bill and the resulting wider discussion of national climate and agricultural policy emphasising failure to keep election promises.

Articles on EU politics were fewer and not directly linked to Swedish agriculture. They focused on general climate policy news, e,g. reports that the EU would not achieve its 
emission targets and preparatory work prior to intergovernmental negotiations. International climate change politics was not a topic until 2009, when the UN Climate Conference came into focus. Reporting from the climate change negotiations contained remarks on the Swedish environmental minister's expectations and the outcome. Paradoxically, articles reported that the negotiation outcomes would not affect Swedish agriculture, while simultaneously claiming that "failure in negotiations would benefit Swedish agriculture". ${ }^{\mathrm{f}}$ The farming magazines displayed ambivalence in their international reporting, drawing no firm conclusions as to whether and how international climate politics would affect the local context.

Articles on climate change politics reported on economic losses and increased taxes, thus introducing an economic burden frame. By calculations of the exact costs for agriculture and stories of individual economic losses, climate change was not presented as an economic opportunity but a challenge. In the rare cases when articles reported on climate change in developing countries, an economic development frame was used, and climate change was related to economic and social development. When climate policy or mitigation was discussed for Swedish agriculture, it was more often framed as an obstacle to economic development.

\subsection{General framing: the importance of taking action}

The frames of conflict, scientific certainty, and economic burden were each primarily connected to a different theme in the farming magazines coverage of climate change. Besides these frames, the content of the magazine articles was organized according to an action frame. This framing was not specifically related to any theme, but served as an implicit organizing principle running throughout the material. Independently of topics, the articles reported on action in response to climate change. The reporting concerned climate change actions taken 
by an organization or individual and comparisons between alternative actions to reduce the impact of climate change. The action frame justified changed behaviour not only in light of stricter climate mitigation policies, but also due to observed or projected climatic changes, and evaluations of the agricultural sector's emissions.

Articles treated the internal climate aims and policies of certain organizations or the actions of individuals. The organizations mentioned were LRF, the International Federation of Agricultural Producers, food producers, and the largest Swedish dairy company. Articles presenting individual actions referred to, among others, the minister for the environment, an EU parliamentarian, and farmers in both Sweden and developing countries. Several articles on agriculture's contribution to national emissions framed climate change mitigation as an individual responsibility to mitigate emissions for individual purposes counter to many other findings that often treat mitigation as a transnational, altruistic form of action. Using terms, e.g. "environmentally aware"g and "climate smart",h,i,j,k,l,m and portraying farmers as savers of the Earth's climate, ${ }^{\mathrm{c}, \mathrm{n}}$ the magazines encourage farmers to reduce emissions as the right thing to do. This is consistent with a morality frame and with the rise of what Koteyko et al. (2010) label an attitudinal dimension of climate change. The action frame is, parallel to the responsibility rhetoric, supported by a desire to prevent farmers from being perceived as "environmental villains", k,o,p,q Actions, e.g. the general mapping and evaluation of GHGs emitted by agricultural activity or farm biogas production, were underpinned by arguments such as "we cannot risk being identified as environmental villains". "When the focus was on promoting GHG emission reduction, the articles used positive value-laden statements, for example, equating reducing emissions to being "climate smart", was too insignificant, and arguing for the financial benefits of reducing GHG emissions. 
Hence, the concern over reputation and image largely support the internal action frame when applied to farmers.

There was also an individual action component when reporting the consequences of government mitigation policies and measures. These articles depicted farmers as victims and described how individuals were affected, often financially, by government policies. These articles were explicit in their moral condemnations: "It's a declaration of war", r,s and "It's a betrayal"s,t . When journalists constructed an economic burden frame, they also applied an injustice frame (Gamson 1992). The injustice frame offered an opportunity to express anger over hardships experienced by farmers. It was also applied in articles reflecting concern over farmers' reputation and image. These articles portrayed farmers as unfairly treated in the media or by consumers. The climate-related articles reflected a sense of limited acting space for farmers both in articles conveying positive messages, such as "The climate investigation identifies farmers as winners", und - more commonly - in negatively value-loaded articles reporting, for example, on "the heavy climate burden",r, or "greater demands on agriculture", $1, x$ These articles start from the assumption that farmers have little potential to change their everyday lives, while strongly emphasizing how others actors' perceptions and decisions affect agriculture.

Climate-related articles also focused explicitly on promoting action by comparing the GHG impacts of various production strategies, examining, e.g., ecological versus conventional farming, peas versus soybean, Swedish versus European diesel, and large-scale versus smallscale production. The focus here was on evaluating and contrasting the climate change impacts of alternative actions, to facilitate doing the "climate right" thing. Some articles also recommended policy-makers to change court rulings on water use, establish a government 
emergency fund for natural disaster relief and oversee drainage and the hunting seasons. The business sector was addressed in articles focusing on climate-labelled food throughout the period in a process-oriented way describing how the labelling systems were evolving and presenting alternative climate label designs. Climate labelling was presented as a business opportunity and promoted action to achieve certification of agricultural products.

\section{Discussion}

Earlier studies of media framings of climate change have found a focus on impacts and consequences. Climate change is discussed in terms of risk, and catastrophe, in tones of misery and doom (Ambler 2007; Boykoff 2008), and emphasizing tipping points "in a sensational and alarming way" (Russil and Nyssa 2009:343). The Pandora's box frame climate change defined as a call for precaution in the face of possible catastrophic consequences (Nisbet and Scheufele 2009) - clearly dominates quality newspaper and tabloid coverage of climate change, while few or no stories concern the opportunities associated with climate change. Compared with the coverage and framing of climate change in Swedish farming magazines, it is interesting to note that, while mainstream media associate climate change with doomsday scenarios, such scenarios were paid considerably less attention in the farming magazines. Oppositely, the farming magazines' reporting on the impacts of climate change was more balanced, or even favoured opportunities rather than challenges, reflecting the general message in national assessments of climate change (SOU 2007:60, SBA 2007). Very few articles referred to a climate crisis, extreme weather events, melting polar ice, or the threat to polar bears, as seen elsewhere, and only one article covered the possible future increase in pest outbreaks. Climate change was not framed as uncontrollable, as it is in the international mainstream media. Since the Swedish news media's coverage of climate change from 2000 to 2007 emphasized catastrophic or extreme weather events, such as the storm of 
January 2005 and heat records (Westander et al. 2008); consistent with international mainstream media coverage of climate change we suggest that Swedish farming magazines likely lack a Pandora's box frame because they are specialized media rather than because of their national context.

Society's overall contribution to GHG emissions has received little attention in mainstream media worldwide; this study demonstrates that contributions to climate change, mainly in terms of GHG emissions, has been a major theme in Swedish farming magazine reporting since 2000. This is consistent with an injustice or a conflict frame uplifting agriculture's contribution relatively to other sectors' contribution. The conflict frame found in the Swedish farming magazine articles differs from the conflict frame identified by Boykoff and Boykoff (2004). They concluded that journalistic norms of balance, giving all sides in a dispute a voice, have resulted in a conflict frame. The conflict portrayed by the Swedish farming magazines does not concern the scientific foundations of climate change, but that journalists use a conflict frame to advocate a certain message. By contrasting and comparing various production systems, national agricultural contexts, and sectors, the farming magazines report on emissions and on how they can be decreased, while simultaneously portraying Swedish farmers as just one of many actors contributing to climate change. The conflict frame is common in mainstream media and our examination suggests that it is also common in specialized media, although the substance of the conflict differs.

The economic burden frame found in farming magazines is less common in mainstream media (Nisbet and Scheufele 2009; Olausson 2009). It frames climate change as individual economic losses stemming from national climate policies. Although climate change is seldom interpreted as a financial and economic issue in mainstream media, Nerlich and Koteyko 
(2010) found that financial papers used the "gold rush" metaphor more frequently than did UK newspapers when referring to climate mitigation. It conveyed an understanding of climate mitigation as limitless opportunities, highlighting prospects for profits. Clearly climate change can be understood as an economic opportunity or burden. While financial papers emphasized the opportunities presented by mitigation schemes, the economic burden frame, attributable to national climate policies, dominated the farming magazines reporting; despite the general focus on opportunities as a result of higher yields due to higher temperatures. This mirrors the fact that Northern European farmers are mainly viewed as climate change winners who, due to stricter climate change policies, could rapidly become losers.

Counter to findings in earlier studies of climate change communication (e.g. Moser 2010), the farming magazines examined seem to make climate change concrete. There is considerable focus on local impacts and individual farmers' responses to climate change, which follows recommendations of climate change communication research emphasizing that messages perceived as containing information of personal relevance to the individual receiver are more likely to motivate the individual to think about the message (O'Neill and Nicholson-Cole 2009). The shift from abstract and general climate narratives describing temporally and spatially distant impacts (Moser and Dilling 2004) towards concrete, observed changes found in this and other studies (e.g. Olausson 2009) probably occurred because the findings of phenological studies had recently become available. These studies demonstrate that climate change is already occurring, and often provide evidence of current and future climate change manifesting itself in specific geographical places and events. Accordingly, rather than being represented as a remote possibility for "others", their impacts are brought into readers' everyday experiences (Carvalho and Burgess 2005). 
This paper has mapped the availability and analyzed the framing of information about climate change in specialized farming magazines. Based on what we know about media habits among Swedish farmers (LRF 2009), it is reasonable that most Swedish farmers today have access to information about causes and impacts of climate change, since the distribution and readership of the studied magazines is widespread. Our study indicates that specialized agricultural media may play an important knowledge broker role, making mitigation and adaptation measures tangible by putting them in a local context closer to farmers' everyday practices. Nevertheless, availability of information is but one of the factors influencing public engagement in climate change (Lorenzoni et al. 2007). Nisbet (2009:16) has emphasized the importance of frame analysis as a means to explain "how media portrayals in interaction with cultural forces shape public views of complex policy debates such as climate change". While it is crucial for climate change communicators and agricultural extension officers to be aware of how media have covered and framed climate-related issues, we also see a need for further research into how media framings interact with cultural forces, social norms and expectations (Lorenzoni et al. 2007), to spur public engagement in climate change.

In the case of Sweden, climate change is presented in the political discourse and in the media as a matter of collective responsibility (Swedish Government Bill 2009; Olausson 2009). Swedish farmers find themselves in a cultural context where trust in authorities and scientists is relatively high (e.g. Viklund 2003), where Government strives to be perceived as leader on climate change (Swedish Government Bill 2009), and where people increasingly state they have done something in their everyday lives to reduce their climate impact (Westander et al. 2008; Olausson 2009). The strong emphasis on collective responsibility in the Swedish cultural and climate policy context could probably explain why the action frame and the scientific certainty frame were so prevalent in the farming magazines. In other cases different 
frames of climate change could be more efficient for fostering engagement. For instance, substituting the economic burden frame for the gold rush metaphor (Nerlich and Koteyko 2010) could potentially resonate with an audience of farmers being keen on innovation and entrepreneurship. This paper studies a country whose agricultural sector is portrayed as a winner, similar as in Canada, Finland, Norway, and the northern US. Interestingly, still we found that an economic burden frame dominated specialized media coverage due to more stringent fuel taxation and that an injustice or conflict frame also was prominent to advocate that agriculture is not the main contributor to climate change. In locations where climate change scenarios suggest deteriorating conditions for agriculture, specialized media is more likely to use the Pandora's box and economic burden frames. We also suggest that the conflict and action frames are likely to be part of specialized media reporting.

In line with previous research into climate change communication (Maibach et al. 2008; Moser 2010), we argue that segmenting target audiences and tailoring messages to the audiences' interpretative frames is necessary. Communicators and agricultural extension officers need to match the content and framing of the message to the knowledge level of their audiences and to their interests, values, and concerns (e.g. Nisbet and Scheufele 2009). Even though farmers could be conceptualized as a homogeneous target group by virtue of their professional activities, there are obviously large variations between national and cultural contexts, farming practices, socio-economic background, and climate vulnerability.

\subsection{Conclusions}

In analyzing framings and coverage of climate change in the two largest Swedish farming magazines between 2000 and 2009, we found that: 
- Coverage of climate change was unevenly distributed temporally. Attention to climate change peaked in 2007 and 2009.

- The most prominent themes in the farming magazines were: agriculture's contribution to climate change, impacts of climate change on agriculture, and consequences of climate politics for agriculture.

- Swedish farming magazines framed climate change differently from Swedish, European and US news media. Unlike them, the farming magazines paid little attention to dystopian scenarios, but favoured a balanced reporting on farmers' roles in contributing to, and being impacted by climate change.

- The most prominent frames in the farming magazines climate-related articles were: the "conflict frame" counter posing different production systems, national agricultural contexts, and sectors; the "scientific certainty frame" presenting scientific findings as unquestionable evidence; the "economic burden frame" emphasizing negative economic consequences for farmers due to climate policies; the "action frame" supported by a morality frame, highlighting action on climate change taken by organizations or individuals, and comparing alternative actions to reduce impact on climate change.

- Climate change communicators addressing farmers and agricultural extension officers should consider how these framings may be interpreted differently among different target audiences.

- Research is needed on how specialized media reports on climate-related issues and how science-based climate information is understood by different groups of farmers and which other factors influence farmers' engagement in climate mitigation and adaptation. Broadening the scope of media studies of climate change communication, 
by including analyses of context-specific media, will complement the findings from analyses of newspaper and television reports.

Acknowledgements: We gratefully acknowledge support from the Swedish Farmers' Foundation for Agricultural Research project "Competitively strengthened agriculture: communication about climate change and new possibilities" and the EU Baltic Sea Region project "BalticClimate". We are grateful to colleagues at the Centre for Climate Science and Policy research and two anonymous reviewers for their productive comments.

\section{References}

Ambler D (2007) Global warming: the social construction of a quasi-reality? Energ Environ 18:805-813

Boykoff MT (2007) Flogging a dead norm? Newspaper coverage of anthropogenic climate change in the United States and United Kingdom from 2003 to 2006. Area 39:470-481

Boykoff MT (2008) The cultural politics of climate change discourse in UK tabloids. Polit Geogr 27:549-569

Boykoff MT, Boykoff JM (2004) Balance as bias: global warming and the US prestige press. Glob Environ Chang 14:125-136

Brossard D, Shanahan J, McComas K (2004) Are issue-cycles culturally constructed? A comparison of French and American coverage of global climate change. Mass Commun Soc 7:359-377

Brunn SD, Raitz KB (1978) Regional patterns of farm magazine publication. Econ Geog 54:277-290 
Carvalho A, Burgess J (2005) Cultural circuits of climate change in U.K. broadsheet newspapers, 1985-2003. Risk Anal 25:1457-1469

FAO (2008) Climate change adaptation and mitigation: challenges and opportunities in the food sector. Information paper HLC/08/INF/2 from High Level Conference on World Food Security. FAO, Rome

Freudenburg WR, Muselli V (2010) Global warming estimates, media expectations, and the asymmetry of scientific challenge. Glob Environ Chang 20:483-491

Gamson WA (1992) Talking politics. Cambridge University Press, Cambridge, UK.

Gamson WA, Modigliani A (1987) The changing culture of affirmative action. In: Braungart R, Braungart M (eds) Research in political sociology, vol. 3. JAI Press, Greenwich, CT, pp 137-177

Greppa Näringen (2011) Klimat. www.greppa.nu Accessed 18 Aug 2011

Hulme, M (2009) Why we disagree about climate change: understanding controversy, inaction and opportunity. Cambridge University Press, Cambridge, UK.

IPCC (2007) Climate Change 2007: Synthesis Report. Contribution of Working Groups I, II and III to the Fourth Assessment Report of the Intergovernmental Panel on Climate Change. IPCC, Geneva, Switzerland

Janssen M, Schoon M, Weimao K, Börner K (2006) Scholarly networks on resilience, vulnerability and adaptation within the human dimension of global environmental change. Glob Env Change 16:240-252

Koteyko N, Thelwall M, Nerlich B (2010) From carbon markets to carbon morality: creative compounds as framing devices in online discourses on climate change mitigation. Sci Commun 32:25-54

LAND LANTBRUK: http://www.sverigestidskrifter.se/medlem/tidskrifter/land-lantbruk Accessed 9 May 2011 
Lorenzoni I, Nicholson-Cole, S, Whitmarsh L (2007) Barriers perceived to engaging with climate change among the UK public and their policy implications. Glob Env Change $17: 445-459$

LRF (2009) Lantbrukarnas medievanor. The Federation of Swedish Farmers, Stockholm LRF Media (2010a) Land Lantbruk: http://www.Irfmedia.se/?LandLantbruk Accessed 9 May 2011

LRF Media (2010b) ATL: http://www.lrfmedia.se/?ATL Accessed 9 May 2011

Lyytimäki J (2011) Mainstreaming climate policy: the role of media coverage in Finland. Mitig Adapt Strat Glob Change 16:649-661

Maibach E, Roser-Renouf C, Leiserowitz A (2008) Communication and marketing as climate change- intervention assets: A public health perspective. Am J Prev Med 35:488-500.

Moser SC (2010) Communicating climate change: history, challenges, process and future directions. Wiley Interdiscip Rev Clim Chang 1:31-53

Moser SC, Dilling L (2004) Making climate hot: communicating the urgency and challenge of global climate change. Environ 46:32-46

Nerlich B, Koteyko N (2010) Carbon gold rush and carbon cowboys: a new chapter in green mythology? Environ Commun 4:37-53

Nisbet MC (2009) Communicating climate change: why frames matter for public engagement. Environ Sci Policy Sustain Dev 51:12-23

Nisbet MC, Scheufele DA (2009) What's next for science communication? Promising directions and lingering distractions. Am J Bot 96:1767-1778

NordForsk (2009) Nordic climate change research. NordForsk Policy Briefs 2009:8. Nordforsk, Oslo

O'Brien K, Leichenko R (2000) Double exposure: assessing the impacts of climate change within the context of economic globalization. Glob Env Change 10:221-232. 
O’Neill S, Nicholson-Cole S (2009) "Fear won't do it": Promoting positive engagement with climate change through visual and iconic representations. Sci Commun 30:355-379.

Olausson U (2009) Global warming-global responsibility? Media frames of collective action and scientific certainty. Public Underst Sci 18:421-436

Russil C, Nyssa Z (2009) The tipping point trend in climate change communication. Glob Environ Chang 19:336-344

Scheufele DA, Tewksbury D (2007) Framing, agenda setting, and priming: the evolution of three media effects models. J Commun 57:9-20

SEPA, Swedish Environmental Protection Agency (2012) National Inventory Report 2012. SEPA, Stockholm, Sweden.

SBA, Swedish Board of Agriculture (2007). En meter i timmen - klimatförändringarnas påverkan på jordbruket i Sverige. Report 2007:16. SBA, Jönköping, Sweden

SBA (2010a). Minskade växtnäringsförluster och växthusgasutsläpp till 2016 - förslag till handlingsprogram för jordbruket. Report 2010:10. SBA, Jönköping, Sweden

SBA (2010b). Konsekvenser för jordbrukets vattenanläggningar i ett förändrat klimat. Report 2010:27. SBA, Jönköping, Sweden

SBA (2011) Facts about Swedish agriculture. Broschure. SBA, Jönköping, Sweden

Swedish Government Bill (2009) An integrated climate and energy policy. Government Bills 2008/09:162 and 163

Swedish Government Official Report (2007) Sweden facing climate change: threats and opportunities. SOU 2007:60

Swedish Magazine Publisher Association (2010) ATL: http://www.sverigestidskrifter.se/medlem/tidskrifter/atl-lantbrukets-affarstidning. Accessed 31 March 2010 
Viklund MJ (2003) Trust and Risk Perception in Western Europe: A Cross-National Study. Risk Anal 23: 727-738

Weingart P, Engels A, Pansegrau P (2000) Risks of communication: discourses on climate change in science, politics, and the mass media. Public Underst Sci 9:261-283

Westander H, Henryson J, Lindberg J (2008) Media och klimatförändringen. Westander Publicitet \& Påverkan, Stockholm

Whitmarsh L, Lorenzoni I (2010) Perceptions, behavior and communication of climate change. Wiley Interdiscip Rev Clim Chang 1:158-161

Young N, Dugas E (2011) Representations of climate change in Canadian national print media: the banalization of global warming. Can Rev Sociol 48:1-22 


\begin{tabular}{|c|c|c|c|}
\hline Note & Magazine & Year, no.:p. & Headline \\
\hline $\mathrm{a}$ & Land Lantbruk & $2000,9: 4$ & $\begin{array}{l}\text { Sverige planerar för kvot med kofis } \\
\text { [Sweden planning cow fart quota] }\end{array}$ \\
\hline $\mathrm{b}$ & Land Lantbruk & $2000,14: 31$ & $\begin{array}{l}\text { Helig ilska kring kofis [Holy anger } \\
\text { about cow farts] }\end{array}$ \\
\hline $\mathrm{c}$ & $A T L$ & $\begin{array}{l}2007,60: 12- \\
13\end{array}$ & $\begin{array}{l}\text { Dags att välja bov i klimatdramat } \\
\text { [Time to choose a villain in the } \\
\text { climate drama] }\end{array}$ \\
\hline $\mathrm{d}$ & $A T L$ & $\begin{array}{l}2009,86: 20- \\
21\end{array}$ & $\begin{array}{l}\text { Bilen eller biffen? Välj själv! [The } \\
\text { car or the steak? You decide!] }\end{array}$ \\
\hline $\mathrm{e}$ & $A T L$ & $2007,68: 8$ & $\begin{array}{l}\text { Krav på skyddsnät för drabbade } \\
\text { bönder [Requirements for safety nets } \\
\text { for affected farmers] }\end{array}$ \\
\hline $\mathrm{f}$ & Land Lantbruk & $\begin{array}{l}2009,46: 20- \\
21\end{array}$ & $\begin{array}{l}\text { Mötesfiasko gynnar Sverige - på } \\
\text { kort sikt [A meeting fiasco favours } \\
\text { Sweden in the short term] }\end{array}$ \\
\hline $\mathrm{g}$ & $A T L$ & $2004,90: 12$ & $\begin{array}{l}\text { Mer ärter och mindre soja [More } \\
\text { peas and less soy] }\end{array}$ \\
\hline $\mathrm{h}$ & $A T L$ & $2008,11: 2$ & $\begin{array}{l}\text { Klimatsmart kyckling och stolta } \\
\text { bönder [Climate-smart chicken and } \\
\text { proud farmers] }\end{array}$ \\
\hline $\mathrm{i}$ & $A T L$ & $2008,31: 2$ & $\begin{array}{l}\text { Råd om klimatsmart mat kräver } \\
\text { uppdatering [Advice on climate- } \\
\text { friendly food needs to be updated] }\end{array}$ \\
\hline $\mathrm{J}$ & $A T L$ & $\begin{array}{l}2009,86: 20- \\
21\end{array}$ & $\begin{array}{l}\text { Osäkra uppgifter om matens } \\
\text { klimatpåverkan [Uncertain data on } \\
\text { the climate effect of food] }\end{array}$ \\
\hline $\mathrm{k}$ & Land Lantbruk & $\begin{array}{l}2007,47: 14- \\
16\end{array}$ & $\begin{array}{l}\text { Klimathotet kräver ett smart jordbruk } \\
\text { [The climate threat requires smart } \\
\text { farming] }\end{array}$ \\
\hline 1 & Land Lantbruk & $\begin{array}{l}2007,49: 18- \\
19\end{array}$ & $\begin{array}{l}\text { Högre krav på bonden ska göra } \\
\text { gården klimatsmart [Higher demands } \\
\text { on farmers to make the farm climate- } \\
\text { smart] }\end{array}$ \\
\hline $\mathrm{m}$ & Land Lantbruk & $\begin{array}{l}2009,22: 18- \\
19\end{array}$ & $\begin{array}{l}\text { Klimatsmartare kött utan soja } \\
\text { [Climate-smarter meat without soy] }\end{array}$ \\
\hline $\mathrm{n}$ & $A T L$ & 2009, 30 Jan:4 & $\begin{array}{l}\text { Jordbruket kan bli lönsammare med } \\
\text { klimatanpassning [Agriculture can } \\
\text { become more profitable by adapting } \\
\text { to climate change] }\end{array}$ \\
\hline o & Land Lantbruk & $\begin{array}{l}2007,47: 14- \\
16\end{array}$ & $\begin{array}{l}\text { Vi kan inte riskera att pekas ut som } \\
\text { miljöbovar [We cannot risk being } \\
\text { identified as environmental villains] }\end{array}$ \\
\hline $\mathrm{p}$ & Land Lantbruk & $2008,32 / 33: 4$ & $\begin{array}{l}\text { LRF vill nyansera bild av mulljord } \\
\text { som miljöbov [LRF wants to change } \\
\text { the image of fertile soils as } \\
\text { environmental villains] }\end{array}$ \\
\hline
\end{tabular}




\begin{tabular}{|c|c|c|c|}
\hline $\mathrm{q}$ & $A T L$ & $\begin{array}{l}2009,86: 20- \\
21\end{array}$ & $\begin{array}{l}\text { Biffen är inte den största } \\
\text { klimatboven [The steak is not the } \\
\text { biggest climate villain] }\end{array}$ \\
\hline $\mathrm{r}$ & $A T L$ & $2009,19: 4-5$ & $\begin{array}{l}\text { Miljöbördan växer för bönderna [The } \\
\text { environmental burden grows for } \\
\text { farmers] }\end{array}$ \\
\hline$S$ & Land Lantbruk & $2009,12: 4-5$ & $\begin{array}{l}\text { LRF:s ordförande: Detta är ett svek } \\
\text { mot oss i de gröna näringarna } \\
\text { [Farmer's federation president: This } \\
\text { is a slap in the face to all green } \\
\text { industry] }\end{array}$ \\
\hline $\mathrm{t}$ & Land Lantbruk & $2009,13: 6-9$ & De sju sveken [The seven betrayals] \\
\hline $\mathrm{u}$ & $A T L$ & $2007,68: 8$ & $\begin{array}{l}\text { Klimatutredningen pekar ut bönderna } \\
\text { som vinnare [The climate } \\
\text { investigation identifies farmers as } \\
\text { winners] }\end{array}$ \\
\hline $\mathrm{V}$ & $A T L$ & $2007,90: 4$ & $\begin{array}{l}\text { Tung klimatbörda för svenska } \\
\text { bönder [Heavy climate burden on } \\
\text { Swedish farmers] }\end{array}$ \\
\hline $\mathrm{x}$ & $A T L$ & $2007,13: 6$ & $\begin{array}{l}\text { Tuffare krav på lantbruket när } \\
\text { utsläppen ska minska [Tougher } \\
\text { demands on agriculture when } \\
\text { emissions are to be decreased] }\end{array}$ \\
\hline
\end{tabular}

